\title{
СИНТЕЗ НОВЫХ ПРОИЗВОДНЫХ \\ 3,4-ДИГИДРОПИРИМИДИН-2(1Н)-ТИОНОВ И ПРОГНОЗ ИХ БИОЛОГИЧЕСКИХ СВОЙСТВ МЕТОДОМ МОЛЕКУЛЯРНОГО ДОКИНГА
}

И.В. Минеева' ${ }^{1}$, Я.В. Фалетров ${ }^{1,2}$, В.А. Старовойтова ${ }^{1,2}$, В.М. Шкуматов ${ }^{1,2}$

${ }^{1}$ Химический факультет, Белорусский Государственный Университет, 220030, Республика Беларусь, г. Минск, пр. Независимости, 4.

${ }^{2}$ НИИ ФХП, Белорусский Государственный Университет,

220006, Республика Беларусь, г. Минск, Ленинградская, 14.

DOI: 10.19163/MedChemRussia2021-2021-426

E-mail: i.mineyeva@yandex.ru

Впервые осуществлен синтез более 30 новых производных 3,4-дигидропиримидин-2(1Н)-она (ДГПТ) посредством мультикомпонентной реакции Биджинелли [1] с использованием алифатических альдегидов, в том числе содержащих циклопропанольные фрагменты, и хлорида европия как катализатора с выходами 51-98\%. Компьютерное моделирование (докинг) показало, что индолильные производные способны эффективно связываться с серин/треонин протеинкиназой (код pdb 3096; Есв = -11 ккал/моль) и казеин-киназой (1eh4, 10,3 ккал/моль). В целом, получены расчетные данные для 10 структур различных белков человека или микроорганизмов. Полученные результаты указывают на возможность получения новых циклопропанольных производных ДГПТ и оценку их биологических свойств методами in silico для целей получения новых молекулярных инструментов и прототипов лекарств.

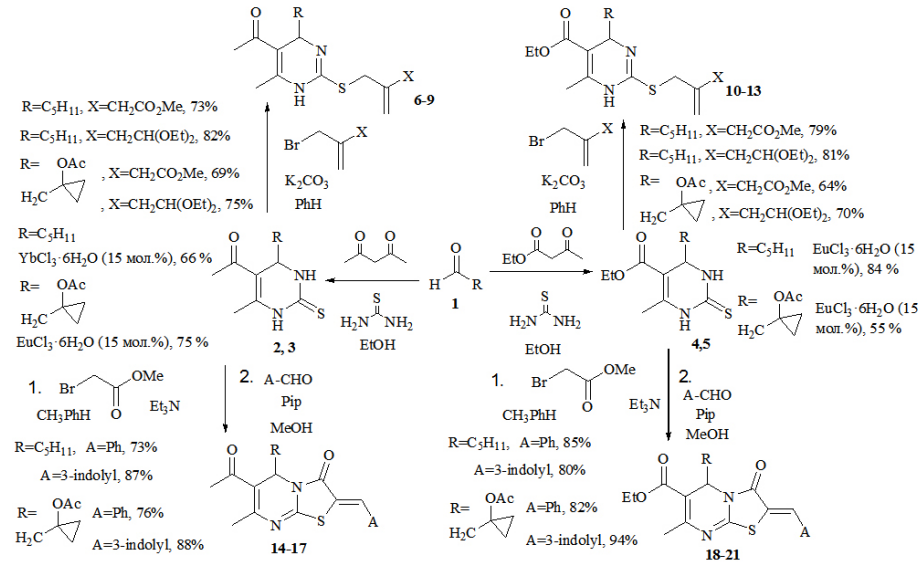

\section{Литература}

[1] R. Kaur, S. Chaudhary, K. Kumar, M. K. Gupta, and R. K. Rawal, Eur. J. Med. Chem. 2017, 132, 108-134. 